\title{
Efficacy of Bacillus thuringiensis israelensis (Bti) and four plant extracts on the mortality and development of Culex quinquefasciatus Say (Diptera: Cullicidae)
}

\author{
Abir A. Gad ${ }^{1 *}$ (D) and Abeer A. Al-Dakhil ${ }^{2}$
}

\begin{abstract}
The efficacy of the bio-insecticide, Bacillus thuringiensis var. israelensis (Bti), and four plant-ethanol extracts Cinnamomum osmophloeum, Matricaria chamomilla, Seasamum indicum, and Nigella sativa was tested against larvae of filarial vector, Culex quinquefasciatus, under laboratory conditions. The Bti and extracts of N. sativa and C. osmophloeum showed the highest insecticidal activity, with $L C_{50}$ values of $7.18,14.59$, and $28.87 \mathrm{mg} / \mathrm{l} 24$ and $48 \mathrm{~h}$ post treatments, respectively. The extracts of $M$. chamomilla and S. indicum were effective. The tested extracts altered some biological aspects of $C X$. quinquefasciatus, i.e., developmental periods, pupation rate, and adult emergence. Pupation rate was suppressed by Bti at $7.5 \mathrm{mg} / \mathrm{l}$ and by C. osmophloeum at $75 \mathrm{mg} / \mathrm{l}$. In addition, the tested plant extracts exhibited various morphological abnormalities of larvae, pupae, and adults.
\end{abstract}

Keywords: Culex quinquefasciatus, Bacillus thuringiensis var. israelensis, Plant extracts

\section{Background}

Mosquitoes are important vectors of etiological agents of diseases to humans and animals. Culex quinquefasciatus is the principal vector of lymphatic filariasis, caused by Wuchereria bancrofti, and it also causes dermatitis (Ramaiah et al. 2006).

The control of mosquito vectors and reducing transmission of human pathogens are depended mainly on the chemical insecticides. However, chemical pesticides have harmful effects on human health and negative effects on non-target organisms and have led to insect resistance.

These problems led to search for new safe materials to control the mosquitoes. Plant extracts beside the bio-insecticide, Bacillus thuringiensis (Bt), which produces specific toxins, are important agents for biological control of the mosquitos. Bacillus thuringiensis var. israelensis (Bti) is one of these inert bio-insecticides. Its toxicity is mainly due to the crystal included in the spore of the bacterium (delta-endotoxin).

\footnotetext{
* Correspondence: abir_gad@yahoo.com

'Applied Entomology, Faculty of Agriculture (El-Shatby), Alexandria

University, Alexandria, Egypt

Full list of author information is available at the end of the article
}

$B t i$ has a high effect on larvae of more than 115 species of mosquitoes and 40 species of black flies. It is extremely effective against mosquito larvae at very low doses and has a safe effect on the non-target organisms and environment. On the other hand, plant oils have obtained value in insect control. They are also safe for the environment, non-pollutant, with no dangerous effect on non-target organisms (Lawler 2017).

Many plant oils have been demonstrated to have an effect against mosquitos' larvae (Singh et al. 2003; Karunamoorthi and Ilango 2010; Phasomkusolsil and Soonwera 2010; Sritabutra et al. 2011).

The aim of this study was to evaluate the larvicidal effect of four plant extracts against $C x$. quinquefasciatus compared to the effect of Bti against Cx. quinquefasciatus under laboratory conditions.

\section{Material and methods Insects}

A laboratory sensitive strain of $C x$. quinquefasciatus was obtained from the College of Food and Agricultural Science, King Saud University, Saudi Arabia. 
This stock colony was maintained at room conditions of $27 \pm 1{ }^{\circ} \mathrm{C}, 70 \%$ R.H., and a photoperiod regime of 14:10 h (L:D). Adult mosquitoes were kept in wooden cages $(30 \times 30 \times 30 \mathrm{~cm})$ and were daily provided by cotton pieces, soaked in $10 \%$ sucrose, for 3-4 days after emergence. Females were allowed to get a blood meal on a pigeon twice a week for egg production. Larvae were reared in plastic cups $(15 \times 15 \mathrm{~cm})$, containing de-chlorinated tap water, under the same room conditions, and were fed daily with a fish food powder. Newly formed 4th instar larvae were used for bioassays.

\section{Tested materials}

Bacillus thuringiensis subsp. israelensis (Bti)

Commercial product (Vectobac ${ }^{\oplus}$ AS-1.200 ITU/mg)

\section{Plant extracts}

Plant materials of Cinnamomum osmophloeum (cinnamon) bark, Matricaria chamomilla (chamomile) whole plant, Seasamum indicum (sesame) seeds, and Nigella sativa (black seed) seeds were collected from different local markets in Saudi Arabia. Identifications were confirmed by the College of Pharmacy, King Saud University.

Samples were air dried, for $48 \mathrm{~h}$, grounded to fine parts, and extracted with ethanol and sometimes heated at $35-40{ }^{\circ} \mathrm{C}$ when necessary. The mixture was stirred for $30 \mathrm{~min}$ by a magnetic stirrer, left for $48 \mathrm{~h}$, and then condensed in a rotary vacuum evaporator of solvent in a water bath at $55{ }^{\circ} \mathrm{C}$ according to Chithra et al. (1998).

\section{Bioassay test}

The larval mortality bioassay was carried out, using the recommended method of the World Health Organization (WHO 1996). Early 4th instar larvae of $C x$. quinquefasciatus were exposed to the four plant extracts and Bti at five to six different concentrations, ranged from 0.75 to $65 \mathrm{mg} / \mathrm{l}$. Twenty 4 th instar larvae per replicate were transferred to a 500 -ml glass beaker, containing $250 \mathrm{ml}$ of de-chlorinated water of different concentrations of Bti and the extracts.
Control was corresponded to $0.1 \mathrm{ml}$ of $70 \%$ ethanol. All assays were repeated three times. Mortality rates were daily recorded, and dead larvae and pupae were counted until adult emergence. Mortality rates were corrected according to Abbott (1925). The mortality data were subjected to probit analysis to estimate the lethal concentration values $\left(\mathrm{LC}_{50}\right)$ of $B t i$ and the plant extracts (Finney 1971).

In order to determine the latent effects of the tested extracts and Bti on some biological aspects, the number of developed pupae at each concentration was counted and the pupae were placed in a separate cage until the emergence of adults. Consequently, the developmental periods, pupation rates, and adults' emergence rates were determined.

\section{Statistical analysis}

$\mathrm{LC}_{50}$ was calculated using the SPSS14.0 (Statistical Package of Social Sciences Inc., USA) software. The $\mathrm{LC}_{50}$ values were considered significantly different if the $95 \%$ confidence did not overlap. The biological data were analyzed by Duncan's multiple test via SPSS program.

\section{Results and discussion}

Larvicidal activity of Bti and plant extracts

All plant extracts and Bti showed pronounced larvicidal activity. After $24 \mathrm{~h}$ of treatments, Bti and N. sativa extract exhibited the highest larvicidal activity with the $\mathrm{LC}_{50}$ values of 7.184 and $14.59 \mathrm{mg} / \mathrm{l}$, respectively (Table 1). Meanwhile, the extract of C. osmophloeum $\left(\mathrm{LC}_{50}=32.10 \mathrm{mg} / \mathrm{l}\right)$ was relatively potent toxicant. The lowest larvicidal activity was observed in the case of $M$. chamomilla and S. indicum extracts $\left(\mathrm{LC}_{50}=51.22\right.$ and $62.53 \mathrm{mg} / \mathrm{l})$, respectively. On the other hand, all tested extracts and Bti showed higher larvicidal activity after $48 \mathrm{~h}$. The results also showed that the plant extracts were less toxic to the larvae than Bti.

Some biological features such as developmental periods, pupation rates, and adult emergence rates were conspicuously varied (Tables 2 and 3). The developmental periods

Table 1 Relative toxicity of Bacillus thuringiensis var. israelensis and four plant extracts against Culex quinquefasciatus after 24- and 48-h exposure

\begin{tabular}{|c|c|c|c|c|c|c|}
\hline \multirow[t]{2}{*}{ Treatments } & \multirow{2}{*}{$\begin{array}{c}L^{L C_{50}{ }^{a}} \\
(\mathrm{mg} / \mathrm{l}) 24 \mathrm{~h}\end{array}$} & \multirow{2}{*}{$\begin{array}{c}\mathrm{LC}_{50}{ }^{\mathrm{b}} \\
(\mathrm{mg} / \mathrm{l}) 48 \mathrm{~h}\end{array}$} & \multicolumn{2}{|c|}{ 95\% Confidence limits (mg/l) } & \multirow[t]{2}{*}{ Slope $\pm \mathrm{SE}^{\mathrm{C}}$} & \multirow{2}{*}{$\begin{array}{l}\text { Relative } \\
\text { toxicity }\end{array}$} \\
\hline & & & Lower & Upper & & \\
\hline Bacillus thuringiensis var. israelensis & 7.184 & 3.987 & 4.704 & 15.431 & $0.733 \pm 0.159$ & 7.38 \\
\hline Nigella sativa & 14.593 & 7.936 & 7.98 & 63.7 & $0.666 \pm 0.163$ & 3.63 \\
\hline Cinnamomum osmophloeum & 28.879 & 17.165 & 13.869 & 147.264 & $0.767 \pm 0.161$ & 1.83 \\
\hline Matricaria chamomilla & 36.96 & 14.093 & 17.63 & 176.890 & $0.651 \pm 0.180$ & 1.43 \\
\hline Seasamum indicum & 53.055 & 20.744 & 17.159 & 270.132 & $0.692 \pm 0.166$ & 1.00 \\
\hline
\end{tabular}

${ }^{a}$ The concentration causing $50 \%$ mortality after $24 \mathrm{~h}$ of exposure

bThe concentration causing $50 \%$ mortality after $48 \mathrm{~h}$ of exposure

'Slope of the concentration-inhibition regression line \pm standard error 
Table 2 Effect of Bacillus thuringiensis var. israelensis and some plant extracts on some biological aspects after treatment of 4th instar larvae of Culex quinquefasciatus

\begin{tabular}{|c|c|c|c|c|c|}
\hline Treatments (mg/l) & Larval duration & Pupation \% & Malformed pupae \% & Adult emergence $\%$ & Malformed adults \% \\
\hline \multicolumn{6}{|c|}{ Bacillus thuringiensis var. israelensis } \\
\hline 0.75 & $3.45 \pm 0.1^{\mathrm{a}}$ & $42 \pm 0.35^{b}$ & 1.65 & $33 \pm 0.12^{b}$ & 12 \\
\hline 1.25 & $3.23 \pm 0.12^{\mathrm{a}}$ & $38 \pm 0.4^{c}$ & 3.33 & $24 \pm 0.13^{c}$ & 11.1 \\
\hline 2.5 & $2.45 \pm 0.14^{b}$ & $23 \pm 0.32^{d}$ & 6.73 & $15 \pm 0.05^{d}$ & 6.2 \\
\hline 5 & $2.14 \pm 0.11^{b}$ & $16 \pm 0.24^{e}$ & 5.00 & $0.0 \pm 0.0^{e}$ & - \\
\hline 7.5 & $2.10 \pm 0.06^{b}$ & $0.0 \pm 0.0^{f}$ & - & $0.0 \pm 0.0^{e}$ & - \\
\hline 10 & $0.94 \pm 0.03^{c}$ & $0.0 \pm 0.0^{f}$ & - & $0.0 \pm 0.0^{e}$ & - \\
\hline Control & $3.39 \pm 0.15^{a}$ & $92 \pm 0.65^{\mathrm{a}}$ & 0.0 & $90 \pm 0.65^{a}$ & 0.0 \\
\hline \multicolumn{6}{|l|}{ Nigella sativa } \\
\hline 10 & $9.60 \pm 0.31^{a}$ & $43.3 \pm 0.32^{b}$ & 6.45 & $66.1 \pm 0.15^{b}$ & 19.5 \\
\hline 25 & $7.24 \pm 0.27^{b}$ & $40 \pm 0.21^{c}$ & 13.67 & $54.4 \pm 0.11^{c}$ & 21.4 \\
\hline 35 & $5.36 \pm 0.17^{c}$ & $33.7 \pm 0.13^{d}$ & 20.0 & $62.5 \pm 0.17^{d}$ & 13.04 \\
\hline 45 & $5.12 \pm 0.14^{c}$ & $26.1 \pm 0.11^{e}$ & 0.0 & $13.4 \pm 0.08^{e}$ & 12.3 \\
\hline 55 & $3.24 \pm 0.06^{d}$ & $18.2 \pm 0.06^{f}$ & 0.0 & $0.0 \pm 0.00^{f}$ & - \\
\hline Control & $3.19 \pm 0.18^{e}$ & $90 \pm 0.63^{\mathrm{a}}$ & 0.0 & $93 \pm 0.15^{a}$ & 0.0 \\
\hline \multicolumn{6}{|c|}{ Cinnamomum osmophloeum } \\
\hline 25 & $10.75 \pm 0.34^{\mathrm{a}}$ & $29 \pm 0.21^{b}$ & 50 & $10 \pm 0.3^{b}$ & 19.5 \\
\hline 35 & $8.63 \pm 0.30^{b}$ & $27 \pm 0.15^{c}$ & 30 & $6 \pm 0.3^{c}$ & 21.2 \\
\hline 50 & $5.63 \pm 0.12^{c}$ & $17 \pm 0.02^{d}$ & 7.8 & $5 \pm 0.3^{d}$ & 12.5 \\
\hline 65 & $5.12 \pm 0.1^{c}$ & $0.0 \pm 0.0^{e}$ & - & $0.0 \pm 0.0^{e}$ & - \\
\hline 75 & $3.36 \pm 0.07^{d}$ & $0.0 \pm 0.0^{e}$ & - & $0.0 \pm 0.0^{e}$ & - \\
\hline Control & $3.43 \pm 0.09^{d}$ & $96 \pm 0.17^{a}$ & 0.0 & $98 \pm 0.3^{\mathrm{a}}$ & 0.0 \\
\hline
\end{tabular}

Means within column followed by letter are not significant different $(P \geq 0.05)$ Duncan's multiple range test

Table 3 Effect of Bacillus thuringiensis var. israelensis and some plant extracts on some biological aspects after treatment of 4th instar larvae of Culex quinquefasciatus

\begin{tabular}{|c|c|c|c|c|c|}
\hline Treatments (mg/l) & Larval duration & Pupation \% & Malformed pupae \% & Adult emergence \% & Malformed adults \% \\
\hline \multicolumn{6}{|c|}{ Matricaria chamomilla } \\
\hline 10 & $9.15 \pm 0.31^{a}$ & $61 \pm 0.54^{b}$ & 12.4 & $28.1 \pm 0.12^{b}$ & 10.0 \\
\hline 25 & $7.45 \pm 0.07^{b}$ & $54 \pm 0.43^{c}$ & 16.45 & $26.3 \pm 0.07^{c}$ & 0.0 \\
\hline 35 & $6.32 \pm 0.05^{c}$ & $31 \pm 0.24^{d}$ & 20.2 & $22 \pm 0.21^{d}$ & 0.0 \\
\hline 45 & $6.12 \pm 0.16^{c}$ & $25 \pm 0.22^{e}$ & 30.4 & $16.6 \pm 0.05^{e}$ & 0.0 \\
\hline 50 & $1.24 \pm 0.03^{e}$ & $13 \pm 0.05^{f}$ & 0.0 & $14.1 \pm 0.07^{f}$ & 0.0 \\
\hline 65 & $1.05 \pm 0.02^{\mathrm{e}}$ & $10 \pm 0.08^{9}$ & 0.0 & $11 \pm 0.04^{g}$ & 0.0 \\
\hline Control & $3.39 \pm 0.15^{\mathrm{a}}$ & $91 \pm 0.32^{a}$ & 0.0 & $96 \pm 0.34^{a}$ & 10.0 \\
\hline \multicolumn{6}{|l|}{ Seasamum indicum } \\
\hline 10 & $3.45 \pm 0.13^{\mathrm{a}}$ & $52 \pm 0.41^{b}$ & 11.4 & $35 \pm 0.14^{b}$ & 10 \\
\hline 25 & $3.47 \pm 0.11^{a}$ & $41 \pm 0.32^{c}$ & 23.5 & $33.1 \pm 0.12^{c}$ & 3.7 \\
\hline 35 & $2.64 \pm 0.16^{b}$ & $28 \pm 0.18^{d}$ & 40.0 & $29.5 \pm 0.21^{d}$ & 0.0 \\
\hline 45 & $2.35 \pm 0.05^{b}$ & $22.7 \pm 0.07^{f}$ & 0.0 & $25 \pm 0.17^{e}$ & 0.0 \\
\hline 50 & $2.12 \pm 0.02^{b}$ & $11.3 \pm 0.03^{9}$ & 0.0 & $20.4 \pm 0.13^{f}$ & 0.0 \\
\hline 65 & $1.33 \pm 0.13^{c}$ & $9.2 \pm 0.32^{a}$ & 0.0 & $17.5 \pm 0.11^{\mathrm{g}}$ & 0.0 \\
\hline Control & $3.42 \pm 0.15^{\mathrm{a}}$ & $92 \pm 0.7^{a}$ & 0.0 & $94 \pm 0.32^{\mathrm{a}}$ & \\
\hline
\end{tabular}


of larval stage were extremely prolonged after treatment with the lowest concentrations of C. osmophloeum, $M$. chamomilla, and $N$. sativa extracts, while the longest larval periods were 10.75 and 9.60 days which were recorded after treatment with $N$. sativa and C. osmophloeum at 10 and $25 \mathrm{mg} / \mathrm{l}$, respectively.

The pupation rates decreased significantly as the concentration increased. The maximum decrease was $16 \%$ at the concentration of $1.25 \mathrm{mg} / \mathrm{l}$ of $B t i, 17 \%$ at the concentration of $50 \mathrm{mg} / \mathrm{l}$ of C. osmophloeum, and $18.2 \%$ at the concentration of $55 \mathrm{mg} / \mathrm{l}$ of $N$. sativa (Table 1).

No adults emerged following treatment with $1.25 \mathrm{mg} / \mathrm{l}$ of Bti and $55 \mathrm{mg} / \mathrm{l}$ of $\mathrm{N}$. sativa. Several forms of morphological malformations resulted from treatments of larvae. The abnormal larvae were pigmented and twisted, as well as larval-pupal intermediates (pharate pupae), whereas the deformed pupae were albino pupae with blackish cephalothoracic. The adult's aberrations were failure in eclosion besides deformed abdomen and legs. With regard to morphological abnormalities, larval and pupal aberration reached the highest values at the concentrations of C. osmophloeum (50\% at concentration of $25 \mathrm{mg} / \mathrm{l}$ and $21.2 \%$ at concentration of $35 \mathrm{mg} / \mathrm{l})$. It is evident that $N$. sativa and M. chamomilla caused the highest effect on pupal stage, 20 and $30.4 \%$ at $35 \mathrm{mg} / \mathrm{l}$, respectively (Tables 2 and 3 ).

In the present study, Bti showed good activity aganist $C x$. quinquefasciatus and caused high mortality.

Also, the plant extracts especially $N$. sativa and $C$. osmophloeum showed high toxicity to the insect.

Obtained results are in agreement with those of Lacey et al. (1984) who observed that Bti and Bacillus sphaericus $(B s)$ were useful in controlling the mosquito larval densities in a wide range of habitats and decreased adult mosquito populations.

Thomas et al. (2017) found that clove and cinnamon oils had high toxicity against laboratory Anopheles gambiae and wild $A n$. arabiensis larvae with $\mathrm{LC}_{50}$ of 159.1 and $131.45 \mu \mathrm{g} / \mathrm{l}$, respectively, $24 \mathrm{~h}$ of post treatment. Ahmed (2007) demonstrated that feeding the adults of An. gambiae on a mixture of $3 \%$ black seed oil and $10 \%$ glucose solution caused a significant reduction in the total number of fully developed oocysts in mosquitoes.

S. indicum, N. sativa, and Allium cepa oils were highly toxic to Culex pipiens (Khater 2003). The methanol extract of the leaves of Atlantia monophylla was effective against immature stages of three mosquito species, $C x$. quinquefasciatus, Anopheles stephensi, and Aedes aegypti, in the laboratory, such a plant exhibited insect regulating activity (Sivagnaname and Kalyanasundaram 2004).

Several authors recorded the morphological abnormalities after application with different plant extracts at sub-lethal concentrations. Pigmented larvae and pharate pupae were reported after treatment with sesame oil
(Khater 2003). Albino pupae were observed after larval-pupal intermediates with fenugreek oil (Halawa 2001). Failure of adult eclosion and deformed abdomen and legs were recorded after treatment with sesame, nigella, and onion oils (Khater 2003).

With reference to biological aspects, the data revealed prolongation of the larval developmental periods, because of treatment with sub-lethal concentrations of $C$. osmophloeum and N. sativa extracts, 10.75 and 9.23 days, respectively. Similar results were recorded on $\mathrm{Cu}$. pipiens after treatment with onion, sesame, and nigella oils, 12.6, 9.3, and 8.5 days, respectively (El-Barky 1993).

The prolongation of developmental periods occurred because plant extracts might have insect growth-regulating activity, which may inhibit insect development (Sivagnaname and Kalyanasundaram 2004).

The delayed effect of some plant extracts, however, is more probably due to a disturbance of the endocrine mechanisms that regulate molting and metamorphosis. This mechanism of action has been assumed previously for most plant extracts (Zebitz 1986).

\section{Conclusions}

The mortality rates of $C x$. quinquefasciatus larvae showed positive correlation with the Bti and tested plant extract concentrations and durations of exposure.

Although C. osmophloeum extract has less toxicity than Bti and N. sativa, it gave potent effect on pupal developmental period and adult emergence rates.

Authors' contributions

The second author agreed to publish the manuscript. Both authors read and approved the final manuscript.

Ethics approval and consent to participate

Not applicable

Consent for publication

Not applicable

Competing interests

The authors declare that they have no competing interests.

\section{Publisher's Note}

Springer Nature remains neutral with regard to jurisdictional claims in published maps and institutional affiliations.

\section{Author details \\ ${ }^{1}$ Applied Entomology, Faculty of Agriculture (El-Shatby), Alexandria University, Alexandria, Egypt. ${ }^{2}$ Biology Department, Faculty of Science, Taibah} University, Al- Madinah, Saudi Arabia.

Received: 1 June 2018 Accepted: 17 July 2018

Published online: 27 July 2018

\section{References}

Abbott WS (1925) A method for computing the effectiveness of an insecticide. J Econ Entomol 18:265-267.

Ahmed AM (2007) A dual effect of the black seed oil on the malaria vector Anopheles gambiae: enhances immunity and reduces the concomitant reproductive cost. J Entomol 4(1):1-19. 
Chithra P, Sajithlal B, Chandrakasan G (1998) Influence of Aloe vera on the glycosaminoglycans in the matrix of healing dermal wounds in rats. $J$ Ethnopharmacol 59:179-186.

El-Barky NM (1993) Effect of some insect growth regulators on Culex pipiens in Qalyubla Governorate. M.Sc. Thesis-Fac. Sci. Zagazi Univ, Benha, p 141.

Finney DJ (1971) Probit analysis, 3rd edn. Cambridge University, Press Cambridge, London.

Halawa SM (2001) Studies on the use of some plant extracts as factors in pest management. Ph. D Thesis Fac. of Agriculture, Moshtohor Zagazig Univ, Benha.

Karunamoorthi K, llango K (2010) Larvicidal activity of Cymbopogon citrates (DC) Stapf and Croton macrostachyus against Anopheles arabiensis Patton, a potent malaria vector. Eur Rev Med Pharmacol Sci 14:57-62.

Khater HF (2003) Bio control of some insects. Ph.D. Thesis- Fac. Vet. Med. Moshtohor, Zagazig Univ, Benha, p 158.

Lacey L, Urbina AMJ, Heitzman CM (1984) Sustained release formulations of Bacillus sphaericus and Bacillus thuringiensis $\mathrm{H}-14$ for control of containerbreeding Culex quinquefasciatus. Mosq News 44(1):26-32.

Lawler SP (2017) Environmental safety review of methoprene and bacterially derived pesticides commonly used for sustained mosquito control. Mosquito 139:335-343.

Phasomkusolsil S, Soonwera M (2010) Insect repellent activity of medicinal plant oils against Aedesaegypti (Linn.) Anopheles minimus (Theobald) and Culex quinquefasciatus (Say) base on protection time and biting rate. Southeast Asian J Trop Med Public Health 41:831-840.

Ramaiah KD, Das PK, Michae E, Guyatt H (2006) The economic burden of Iymphatic filariasis in India. Parasitol Today 16:251-253.

Singh NP, Kumari V, Chauhan D (2003) Mosquito larvicidal properties of the leaf extract of a herbaceous plant, Ocimumcanum (Family: Labitae). J Commun Dis 35:43-45.

Sivagnaname N, Kalyanasundaram M (2004) Laboratory evaluation of methanolic extract of Atlantia monophylla (Family: Rutaceae) against immature stages of mosquitoes and non-target organism. Mem Inst Oswaldo Cruz 99:115-118.

Sritabutra D, Soonwera M, Waltanachanobon S, Poungjai S (2011) Evaluation of herbal essential oil as repellents against Aedes aegypti (L.) and Anopheles dirus Peyton \& Harrion. Asian Pac J Trop Biomed (1):S124-S128.

Thomas A, Humphre DM, Alphaxard M, Eliningaya JK (2017) Evaluation of active ingredients and larvicidal activity of clove and cinnamon essential oils against Anopheles gambiae (sensulato). Parasit Vectors 10:411.

WHO (1996). Report of the WHO Informal Consultation on the Evaluation on the Testing of Insecticides CTD/WHO PES/ICL96.1.P.69.

Zebitz CP (1986) Effects of three different neem seed kernel extracts and azadirachtin on the larvae of different mosquito species. J Appl Entomol 102: 455-463.

\section{Submit your manuscript to a SpringerOpen ${ }^{\circ}$ journal and benefit from:}

- Convenient online submission

- Rigorous peer review

- Open access: articles freely available online

- High visibility within the field

- Retaining the copyright to your article

Submit your next manuscript at $\boldsymbol{\nabla}$ springeropen.com 